\title{
Três gravações de campo na cidade do Rio de Janeiro
}

\section{Three field recordings in the city of Rio de Janeiro}

Alexandre Sperandéo Fenerich ${ }^{1}$ Universidade Federal do Estado do Rio de Janeiro alexandre.fenerich@unirio.br 


\section{Resumo}

O artigo apresenta três caminhadas para escuta e captação fotográfica e fonográfica pelo autor por uma região da cidade do Rio de Janeiro, além de uma análise poética do material obtido. A fim de embasar a análise, faz uma revisão teórica que busca entrelaçar conceitos ligados ao deslocamento urbano e à escuta. A partir da tese de Steven Feld (2015), que parte da premissa de que o som é objeto de conhecimento de tecidos sociais, o sonoro pode se manifestar como foco da investigação dos lugares visitados que, pelas suas características urbanas, podem ser entendidos, no contexto da cidade contemporânea, como espaços negativos (SANTOS, 1994) ou espaços opacos (CARERI, 2017) - conceitos que terão repercussões nas três narrativas descritivo-analíticas. O material obtido procura inter-relacionar os registros textuais e fotográficos com o sonoro, a fim de contextualizar sua escuta. Apesar de uma das incursões resultar em uma instalação sonora, o material sonoro e visual obtido nas incursões é anterior a uma realização artística no formato obra, sendo que tanto sua escuta quanto as análises que seguem neste texto constituem parte de um processo composicional em curso ou, ao menos, uma metodologia para criação sonoro-musical a partir de gravações de campo.

Palavras-chave: Gravação de campo; escuta; caminhadas urbanas; espaço negativo; espaço opaco.

\section{Abstract}

This paper presents three walks whose intention were either the listening of a region of Rio de Janeiro as well as its photographic and phonographic takings, therefore making a poetic analysis of the material. In order to support the analysis, a bibliographic revision relating concepts from urban mobility and listening is made. Taking the thesis of Steven Feld (2015) as starting point, in which the sound is understood as an object for the social tissue's knowledge, the sonority of the visited places is taken as focus for the discussion. Those places can be understood, by their urban characteristics in the context of the contemporary city, as negative spaces (Milton Santos, 1994) or opaque spaces(Francesco Careri, 2017) - and those concepts will have significant repercussions on the incursions's narratives. The obtained material intends to interrelate the textual and photographic registers with the sounded register in order to contextualize its listening. In spite of one of the incursions has resulted on a sound installation, the material is previous any artistic realization in a work format and either its analysis as its listening are part of a current compositional process or, at least, of a sound/musical creation from field recordings.

Keywords: Field recording; listening; urban walks; negative spaces; opaque spaces.

\footnotetext{
${ }^{1}$ Compositor e sound designer. Doutor em Musicologia pela USP. Professor adjunto do Instituto Villa-Lobos e do Programa de Pós-Graduação em Música da UNIRIO. Atualmente é professor visitante na UniversitätderKunst, Berlim, com bolsa Capes-Humboldt. Trabalhacom composição musical sobre mídias digitais, com foco em "live eletronics", espacialização aural e performances audiovisuais ao vivo. Participou de projetos inter-nacionais como compositor e "sound designer" na Alemanha, Portugal e Brasil, além de diversos festivais de música e artes digitais. https:/orcid.org/0000-0003-2868-2499
} 


\section{Introdução}

Este artigo trata da investigação estética de uma região da cidade do Rio de Janeiro através de visitas a pé para captações sonoras com microfones binaurais ${ }^{2}$. $O$ texto convoca um momento do processo criativo anterior à realização de um trabalho artístico. Embora tenha gerado uma obra em específico - a instalação Jebebiracica, da qual trataremos adiante -, os resultados materiais são extratos sonoros sem edições publicados em um site, aos quais nos reportaremos oportunamente, além de ensaios textuais que se prestam a criar no ouvinte um contexto, como o que ora apresentamos. Nossa proposta se coloca, desse modo, como reflexão acerca do material já coletado, mas também parte do processo de criação de trabalhos artísticos ainda em desenvolvimento ou na qualidade de porvir.

Como habitante recente da região abordada, a Praça da Bandeira - área que permeia todo o antigo Aterro do Mangue, que compreende do Centro à Zona Norte da cidade -, fiz três "expedições" para escuta e captações fotográficas e fonográficas no seu entorno, em 27 de abril e 5 de setembro de 2018 e entre janeiro e março de 2019. Nestas incursões, a fim de realizar um itinerário possível de ser alcançado a pé, procurei coletar elementos visuais e sonoros que guiassem minha memória e preenchessem minha imaginação com personagens e trajetórias. Neste exercício a-turístico, eu, que não sou nascido no Rio de Janeiro, desejei traçar uma experiência que não se baseasse no exotismo, mas no próprio lugar onde vivo, ao qual ainda não pertenço, mas que é, entretanto, a minha vizinhança.

Nosso texto pretende, assim, dar conta destas incursões em três "narrativas de viagem". Tentei resgatar os personagens e elementos das redondezas a partir de pistas visuais e sonoras deixadas pela paisagem e pelos passantes a despeito do implacável silenciamento e desaparecimento de populações e paisagens vividos há séculos pela cidade. Esses processos ressoam em profundas mudanças sociais e políticas, além do aspecto atual dos muitos rios que compõem a região. Trata-se sobretudo de uma investigação sônica, mas tanto os elementos fotográficos quanto os textuais são essenciais para a formulação de um contexto para a imaginação do ouvinte. Neste artigo, portanto, além de discussões sobre o método, serão apresentadas três narrativas que, junto com as imagens visuais, serão complementares à escuta do material em áudio.

Com respeito a este material, a opção pelo uso de microfones binaurais foi feita por duas razões. A primeira é que estes são dispositivos discretos que, disfarçados de fones de ouvido, não tornam evidente o ato da gravação, e, desta forma, não criam nos passantes, que não se sabem gravados, um estranhamento que impediria a tentativa de captar uma "espontânea" sonoridade das ruas. Um outro aspecto é que a representação feita por tais microfones dá a ilusão da minha própria escuta - ou de uma escuta em primeira pessoa -, pois estabelece uma estereofonia baseada nas dimensões da minha cabeça, visto estarem instalados em minhas orelhas. Assim, todos os movimentos

2 Nào é objeto deste trabalho analisar nem as caracteristicas técnicas da captaçao binaural nem seus modelos psicoacústicos. Para uma breve introdução, ver La Burthe (2017). Para mais detalhes concernentes a aspectos psicoacísticos, ver Gilkey e Anderson (2014). 
corporais - de modo algum planejados durante minhas incursões - foram registrados pelas gravações, e a minha presença física realizada pelos passos, respiração, diálogos e erros de gravação foi preservada pelo áudio.

Sob a perspectiva das poéticas ligadas ao som, a caminhada como meio para a criação sonora tem sido abordada pela música eletroacústica praticamente desde sua origem. O primeiro trabalho de grande fôlego da música concreta, a Symphonie pour un Homme Seul, de 1950, é uma investigação híbrida cênico-musical (FENERICH, 2012) sobre "o homem e seu grito solitário" na multidão (SCHAEFFER, 1952), sendo que nela se escutam tanto o sons dos passos do personagem-título quanto buzinas e sons vertiginosos que remetem a uma deambulação urbana. Por outro lado, os trabalhos do compositor francês Luc Ferrari Presque Rien no 1 e $n^{\circ} 2$ (1970 e 1977 - CAUX, 2002), marcos na ruptura com os preceitos iniciais da música concreta que a aproximam de uma ideia de música pura (KIM-COHEN, 2009), constituem modelos para a presente investigação. A segunda peça, que nos interessa particularmente, demonstra como vestígios do próprio autor aparecem tanto ao andar quanto em comentários sobre os sons captados, de modo que a cena apresentada faz parte da própria realização da peça. Com isso, a peça traz para a escuta a imagem da presença do autor-personagem no espaço em que foi feita a captação, além da apreensão de que a investigação deste espaço se realizou tanto pela escuta atenta dos seus sons quanto por uma deambulação. Além disso, ao apresentar registros sonoros cuja edição visa "entrar na própria sociedade" (CAUX; FERRARI, 1992), Ferrari busca "abrir o domínio da música experimental para não especialistas" (DROTT, 2009).

A prática de realizar caminhadas silenciosas a fim de escutar o ambiente foi sistematizada e denominada soundwalks pela compositora alemã Hildegard Westerkamp, que desde os anos setenta propõe passeios coletivos em percursos predeterminados por ela, em geral em locais silenciosos e calmos, com o objetivo de "incrementar uma consciência geral sobre o ambiente acústico" (WESTERKAMP, 2006). Por incluir o espectador nos passeios, ela enfatiza sua participação no espaço a ser escutado, já que este passa a compô-lo pela sua própria presença.

Signatários das poéticas artísticas dos anos sessenta, as obras de Ferrari e Westerkamp são, no nosso entendimento, balizas importantes para se compreender as produções contemporâneas. Em seus trabalhos percebe-se um movimento de escape das questões "intrinsecamente musicais" em que elementos estritamente formais são a base da realização e da comunicação musical. Parafraseando Foster (2014, p.173), estes trabalhos ampliam o enquadramento musical para o campo da cultura, pois abrem a fruição estética para além da obra musical circunscrita por "valores musicais", pensada como a articulação de motivos ou formas abstratas. As abordagens de Ferrari ampliam a fruição para a apreensão de uma cena - o que faz também o trabalho de Schaeffer e Henry supracitado, embora não explicitamente. As abordagens de Westerkamp ampliam literalmente o espaço da fruição musical, antes restrito a salas de concerto. Finalmente, Ferrari e Westerkamp desviam o escopo musical confinado a um campo exclusivamente sonoro para preocupações sociais ou ecológicas.

Explorações seminais que congregam a caminhada e a escuta, estes trabalhos 
inauguram o gênero soundwalk, realizado por artistas/compositoras, como a alemã Christina Kubisc ${ }^{3}$ e a canadense Janet Cardiff ${ }^{4}$. Entretanto, o escopo desta geração inicial ligada às práticas artísticas dos anos sessenta, demasiado amplo, visava colocar as questões básicas relativas à ruptura com a realização e fruição musical anterior: sua própria forma é seu conteúdo. Mas, uma vez instaurado o gênero, investigações mais específicas de determinados lugares, físicos ou sociais, passam a ser realizadas: o foco se desloca da forma em si para o conteúdo, uma vez que a forma já é apreendida por artistas e pelo público. A obra passa a ser dispositivo de investigação da relação entre o músico ou artista - muitas vezes confundido com um etnógrafo - e o lugar que visita ou do qual capta os sons.

Este papel do artista como etnógrafo é analisado por Foster, que aponta algumas dificuldades intrínsecas a certas poéticas contemporâneas que buscam no outro etnográfico um modelo ou lugar de questionamento das instituições e da moral burguesa (FOSTER, 2014, p.161). Para o autor, muitas vezes essa "alterização do eu" através da comparação de seus desejos com esse outro é mera "autorrestauração narcisista" (FOSTER, 2014, p.168). No entanto, tal olhar no espelho só faz sentido quando há um outro a quem comparar. Mas, quando as investigações são realizadas na própria cidade em que se vive, por exemplo, não há propriamente alteridade, e a descoberta se dá no aprofundamento lento e contínuo do cotidiano. Neste processo, nos interessa observar o intervalo entre o sujeito que visita e os lugares representados, e sua escuta estará impressa pelos trajetos e pela seleção dada pela mirada do microfone e da edição.

Além disso, a disseminação desta prática se acentua pela maior acessibilidade a gravadores portáteis e a sistemas de captação binaural, o que permitiu que músicos e artistas de todo o mundo pudessem realizá-la. Neste sentido, cabe perguntar se haveria diferença entre as estratégias de soundwalk feitas por artistas ao norte ou ao sul globais quanto à forma de fazê-lo ou mesmo sobre os lugares representados. Suas intenções coincidiriam?

A artista mexicana Amanda Gutierrez aponta uma resposta: para ela, o personagem do flâneur só pode ser um homem branco e europeu caminhando na Europa, visto que uma mulher latino-americana no México (como é o seu caso) dificilmente teria a disponibilidade ou a segurança para fazê-lo, e isso implica uma postura corporal na cidade completamente diferente entre um e outro sujeitos, que decorre em diversas representações do espaço (GUTIERREZ, 2018, p.324). Uma vez que os modelos instaurados pelo gênero soundwalk (mediado ou não por tecnologias de gravação) foram feitos pelos artistas acima enumerados, todos europeus, esperamos esmiuçar um modo de autorrepresentação que deles diverge, propondo também uma reflexão crítica acerca desta provável diferença.

Pois as experiências que apresentarei aqui não são meras apresentações das caminhadas em si, mas uma investigação de um espaço social através da caminhada e da gravação (tal é o método do trabalho). Resulta em uma representação parcial dada pela

3 Em Electrical Walks, por exemplo. Disponivel em: http:/www.christinakubisch.de/en/works/electrical_walks.

4 A canadense possui uma série de trabalhos relativos ao tema. Cf. The Walk Book (2005). 
presença nunca naturalizada nos espaços visitados, visto que crio um intervalo social com os lugares que visito. Assim, o material é posteriormente escutado e editado na direção do sentido que a experiência deu quando confrontada com as ideias e teorias prévias. Além disso, os áudios apresentados aqui - exceto no caso da terceira narrativa - não são ainda trabalhos sonoros, mas material em estado semioriginal, no qual apenas edição prévia foi feita. Serão talvez trabalhos no futuro, mas isto não é importante, já que gostaria de discutir neste artigo tanto a incursão em uma mesma região - e portanto aspectos deste lugar dados por sucessivas escutas - quanto o modo de fazê-la.

O texto que segue terá três momentos distintos. O próximo trecho tratará da caminhada como método para a criação musical. Constitui, portanto, uma base teórica para entendê-la. $\mathrm{O}$ momento seguinte refere-se a quatro narrativas relativas às três visitas. Finalmente, como conclusão, aproximarei as narrativas com as reflexões teóricas já apresentadas.

\section{A caminhada e a escuta como métodos para a criação musical}

A caminhada, em oposição a outros modos de deslocamento, caracteriza-se como experiência contínua do espaço que pressupõe um transcorrer ao mesmo tempo lento e intensivo. O geógrafo brasileiro Milton Santos debruça-se sobre as qualidades dos homens lentos, como denomina os sujeitos que detêm este modo de se situar nos espaços urbanos, a caminhada. Para Santos, estes não podem esquadrinhar a cidade na velocidade vertiginosa dos meios de transporte contemporâneos ou das trocas de informações e capitais que as tecnologias digitais proporcionam. Em oposição aos homens lentos, "envoltos nas teias de uma racionalidade invasora de todos os arcanos da vida" (SANTOS, 1997, p.85), se movimentam os que podem transcorrê-la no andamento exigido pela economia globalizada do mundo contemporâneo. Para Santos, os homens velozes "acabam por ver pouco da Cidade e do Mundo", sendo que "sua comunhão com as imagens, frequentemente prefabricadas, é sua perdição" (SANTOS, 1997, p.85). Já os homens lentos, por não poderem acompanhar a velocidade das imagens oferecidas pela mídia ou pelo capital, "acabam descobrindo fabulações” (SANTOS, 1997, p.85) nos seus percursos cotidianos povoados de encontros com o novo.

Tomada como mote para a criação sonora ou musical, a caminhada coloca o corpo em outra condição em comparação ao modelo tradicional das práticas e escutas musicais e sonoras. Põe os sentidos em alerta para o espaço exterior, sendo diretamente implicados no lugar físico e social em que se inserem: a escuta é voltada para fora, e não para os próprios sons daquele que os produz. Situa-se no tecido da vida social. Os ouvintes de trabalhos que exploram gravações de percursos são levados a moverem-se com a escuta apresentada, tendo seu próprio corpo implicado na ação de escutar. Este processo de identificação é similar ao que se dá, por exemplo, na escuta acusmática de sons instrumentais, na qual, sem ver o gesto que gerou os sons, os imaginamos por "anos de treinamento audiovisual (inconsciente)" (SMALLEY, 1999, p.77)-decorrente de nossa experiência de escuta normal da realização musical. 
Para a apreensão de fenômenos sociais, o som é uma forma privilegiada de conhecimento. Feld (2015, p. 14) afirma que sua fisicalidade é "tão instantânea e forçosamente presente à experiência quanto a quem experiencia". Para o etnomusicólogo, a escuta convoca um "saber em ação", para além de especulações metafísicas sobre uma "verdade em abstrato" (FELD, 2015, p. 14). Ela congrega o contexto da produção sonora com uma coparticipação do observador-ouvinte no ambiente, implicando-o no fenômeno natural ou social, já que partilha o espaço com os emissores do som: "a emissão sonora e a escuta alimentam um ao outro"5 (FELD, 2015, p.14, tradução nossa). Para o filósofo Jean-Luc Nancy (2007), por sua vez, o sonoro, em oposição ao visual, que para ele possui maior isomorfismo com o conceito, "supera a forma" ao "não dissolvê-la, mas ampliá-la, fornecê-la uma amplitude, uma densidade e uma vibração ou uma ondulação cujo contorno é apenas aproximado" (NANCY, 2007, p. 2). O som traria, portanto, corporeidade e um senso de copertencimento ao contexto de sua produção. A escuta é, assim, como a caminhada, uma prática intensiva e contínua.

A pesquisa sonora por via de caminhadas urbanas busca apreender o movimento lento como um processo e estado físico oposto à onipresença da velocidade, valor e modo de vida privilegiado nas cidades contemporâneas. Privilegia-se a lentidão dos pés em oposição à troca instantânea de capitais e informação na era pós-digital. A cidade contemporânea é planejada e remodelada não para caminhantes, mas para ser percorrida por carros, ônibus, trens ou metrô. Nesta cidade, caminhar é perder o tempo que poderia ser gasto produzindo ou consumindo - o consumo como corolário do lazer: "velocidade exacerbada que não tem nem busca nem sentido" e que "serve à competitividade desabrida, coisa que ninguém sabe para o que realmente serve, de um ponto de vista moral ou social" (SANTOS, 2001, p.2). Nesta concepção de cidade não se caminha, pois "caminhar significa enfrentar muitos medos: medo da cidade, medo do espaço público, medo de ultrapassar barreiras muitas vezes inexistentes e medo dos outros cidadãos, quase sempre percebidos como inimigos potenciais" (CARERI, 2013, p.170).

Vencer os medos; caminhar é recuperar a velocidade do percurso contínuo (SOLNIT, 2016), sendo atividade intensa nos detalhes oferecidos aos sentidos, se compararmos com a monotonia da viagem rodoviária ou metroviária. Caminhar é uma estratégia de criação artística que resgata uma experiência plana da cidade, para além da contemplação distanciada de uma urbe-cartão postal, como por exemplo em certo projeto do Rio de Janeiro, emblemático nas obras de pura espetacularização do Porto Maravilha e da remodelação da Praça Mauá. É uma prática de errância a qual "se afirma como possibilidade de experiência urbana, uma possibilidade de crítica, resistência ou insurgência contra a ideia de empobrecimento, perda ou destruição da experiência" (BERENSTEIN, 2014, p.27). Experiência da cidade que se perde na cidade racionalizada pelas lógicas do turismo, do consumo ou da técnica. Propõe-se assim um confronto com uma outra cidade, diferente daquela de nossos percursos habituais, a fim de extenuar a experiência, levando-a a um limite possível - o qual é, aliás, geográfico, visto que se impõe na experimentação dos percursos num território como o Rio de Janeiro: de fato, os medos aqui 
são oriundos muitas vezes de ameaças reais, pois há zonas limítrofes que não podem ser ultrapassadas sem permissão ou guia, sob risco da própria vida.

A escolha geral dos percursos é, assim, essencial para a pesquisa. Onde nos resta, então, caminhar? Nem os espaços formatados pelo capital nem os que oferecem perigo fatal: ambos são bem demarcados em sua racionalidade. Buscaremos, por isso, para usar as palavras do geógrafo Milton Santos, espaços opacos, ou seja, opostos ao que ele também chama de "áreas luminosas", onde há "a naturalidade do objeto técnico uma mecânica repetitiva, um sistema de gestos sem surpresa" (SANTOS, 1994, p.83). Os espaços opacos, para o geógrafo, são "espaços do aproximativo", "espaços inorgânicos, abertos", "espaços da lentidão, e não da vertigem", em oposição aos "espaços da exatidão, racionalizados e racionalizadores” (SANTOS, 1994, p.83). Em outro autor, o arquiteto italiano Francesco Careri, encontramos ecos dos conceitos de Santos, que nos provocam:

\footnotetext{
Áreas esquecidas que formam o negativo da cidade contemporânea [...]. Lugares difíceis de serem compreendidos e, consequentemente, de serem projetados [...] pelo fato de não possuírem uma localização presente, de não conhecerem a linguagem do contemporâneo. (CARERI, 2017, p.15).
}

Nesse sentido, estes são os espaços onde transitam ou moram os "homens lentos", que percorrem e esquadrinham a cidade com dificuldade (SANTOS, 1994, p.84), para quem as imagens produzidas pelo capitalismo contemporâneo "são miragens" (SANTOS, 1994, p.84). Circulam pela urbe muitas vezes a pé ou gastam longos períodos no precário sistema de transporte público. São os trabalhadores ou habitantes das ruas: garis, vendedores ambulantes, prostitutas, ou ainda os moradores de rua ou os loucos. Coabitam a cidade em outra temporalidade social e técnica (SANTOS, 2001, p.2) e possuem uma vivência do espaço urbano distinta da minha, que o percorro de modo sedentário e veloz. Colocar-me na mesma condição de escuta de uma cidade cruzada por diversos obstáculos físicos e temporalidades foi a metodologia adotada nas três caminhadas de escuta. Nelas, o gesto contínuo da experiência da caminhada se aproxima de uma experiência da escuta.

As três "expedições" foram realizadas na baía Jebebiracica, antigo nome tupinambá para a enorme área onde atualmente se situa a Zona Norte do Rio de Janeiro e que compreende os rios Maracanã (que é também um nome tupinambá), Trapicheiros, Joana e Comprido. Esta área foi um mangue com muitos outros pequenos rios, mas a paisagem original foi completamente transformada no século XIX, quando todos os rios foram canalizados e algumas avenidas foram criadas. Passarei a narrar a seguir cada uma das três expedições.

\section{27 de abril de 2018: Praça da Bandeira, rua Ceará e Quinta da Boa Vista}

Parti da Praça da Bandeira - um bairro entre a Tijuca, uma região mais rica, e 
áreas mais arcaicas da cidade, como o antigo bairro imperial, São Cristóvão, e o Morro da Mangueira. Cruzei a rampa de pedestres sobre a Radial Oeste, uma avenida contemporânea quase exclusivamente dedicada a carros e ônibus, e entrei na rua Ceará. Daí caminhei até a avenida Pedro II e virei à esquerda, chegando aos arredores da Quinta da Boa Vista. Este é um parque que compreende o zoológico e o antigo palácio imperial, transformado em museu (Museu Nacional da Quinta da Boa Vista) e em alguns departamentos da Universidade Federal do Rio de Janeiro (UFRJ). Em 8 de setembro de 2018, o complexo foi totalmente destruído por um enorme e inexplicável incêndio. Esta primeira narrativa trata do itinerário já descrito, e também se refere constantemente a um áudio postado no link https://soundcloud.com/user-472241268/rio-mangue-soundwalking, o qual sugiro que o leitor escute à medida em que eu for mencionando pontos específicos.
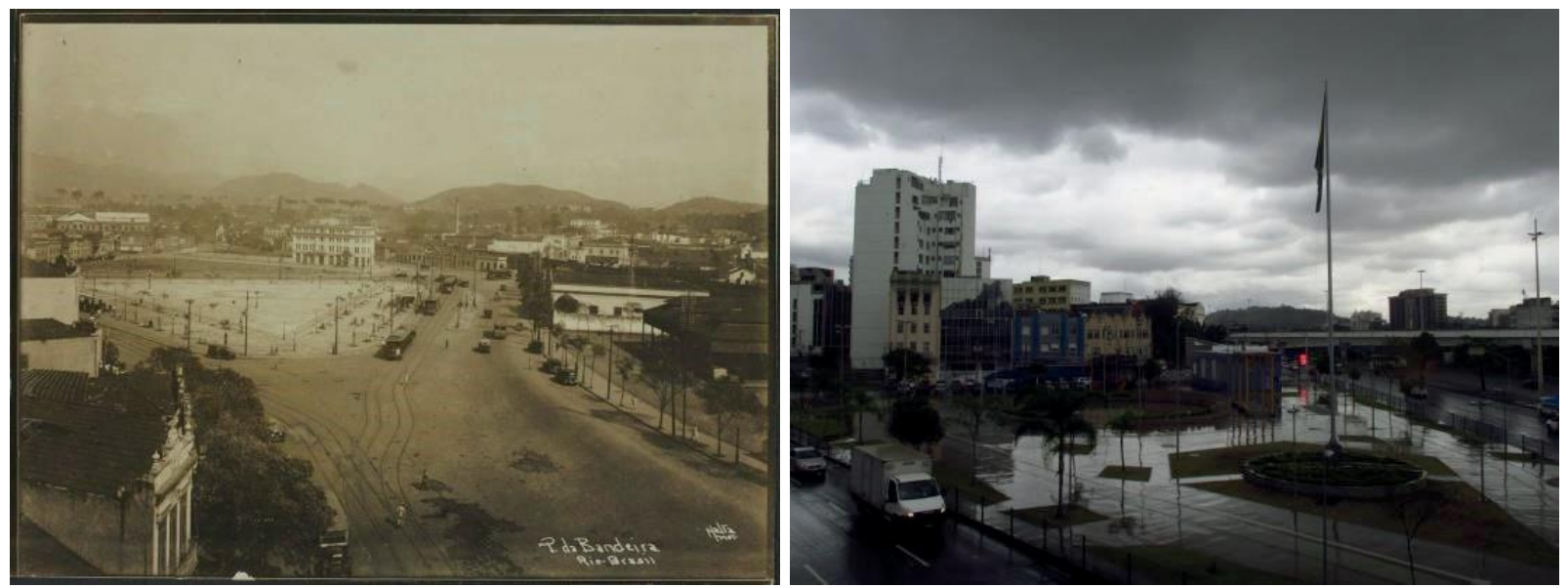

Fig. 1: Praça da Bandeira. Fotografia de Augusto Malta (1906). Fonte: FBN (Fundação Biblioteca Nacional, on-line).

Fig. 2: Praça da Bandeira. Fotografia do autor tirada da rampa de pedestres da Praça da Bandeira, Rio de Janeiro (2018).

A rua Ceará foi meu principal itinerário. É talvez o trecho socialmente mais frágil da região e já foi uma zona de prostituição, hoje em decadência. Entretanto meu percurso foi muito mais extenso: caminhei pelo antigo aterro do enorme mangue (São Diego), um tipo de vegetação que, até o início do século XIX, podia ser encontrado da praia de Santa Luzia até a do Caju, que não existem mais. 


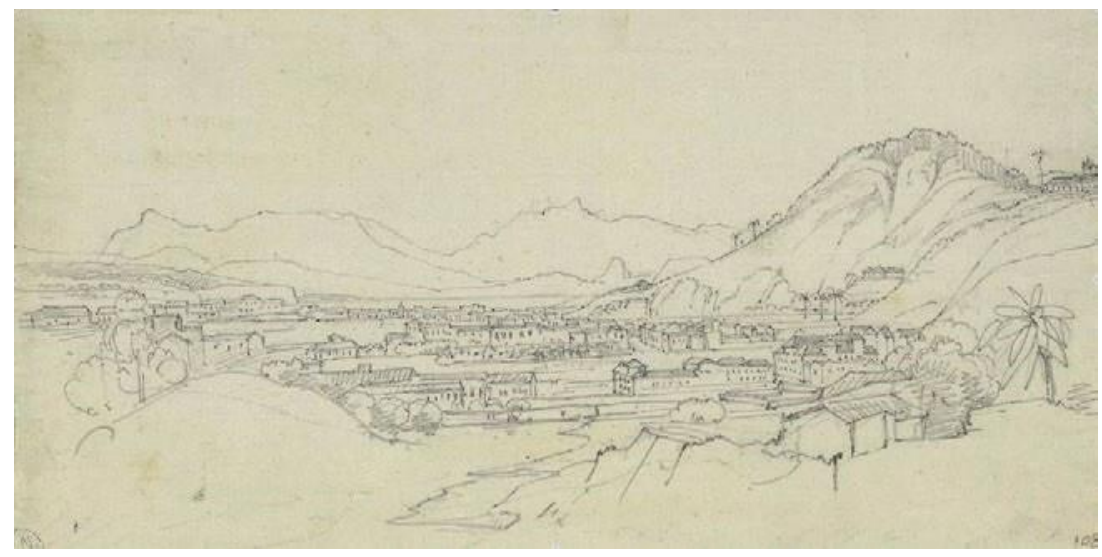

Fig. 3: Mangues de São Diogo. Desenho de Thomas Ender, sem data (século XIX). Fonte: FBN (on-line).

Encontrei aí grandes terrenos vazios de um sistema ferroviário desativado, avenidas intransponíveis a pedestres, viadutos sobre regiões inteiras e canais de concreto que guardam águas mortas que antes foram rios (alguns com papel central no desenvolvimento da cidade, como o Maracanã) e que agora são esgoto a céu aberto que desemboca na Baía de Guanabara. Também me deparei com lojinhas precárias e residências improvisadas entre pontes ferroviárias de ferro fundido, que remontam ao início do século $X X^{6}$. Os primeiros números da rua Ceará são uma área esquecida da cidade, como que fora do tempo.

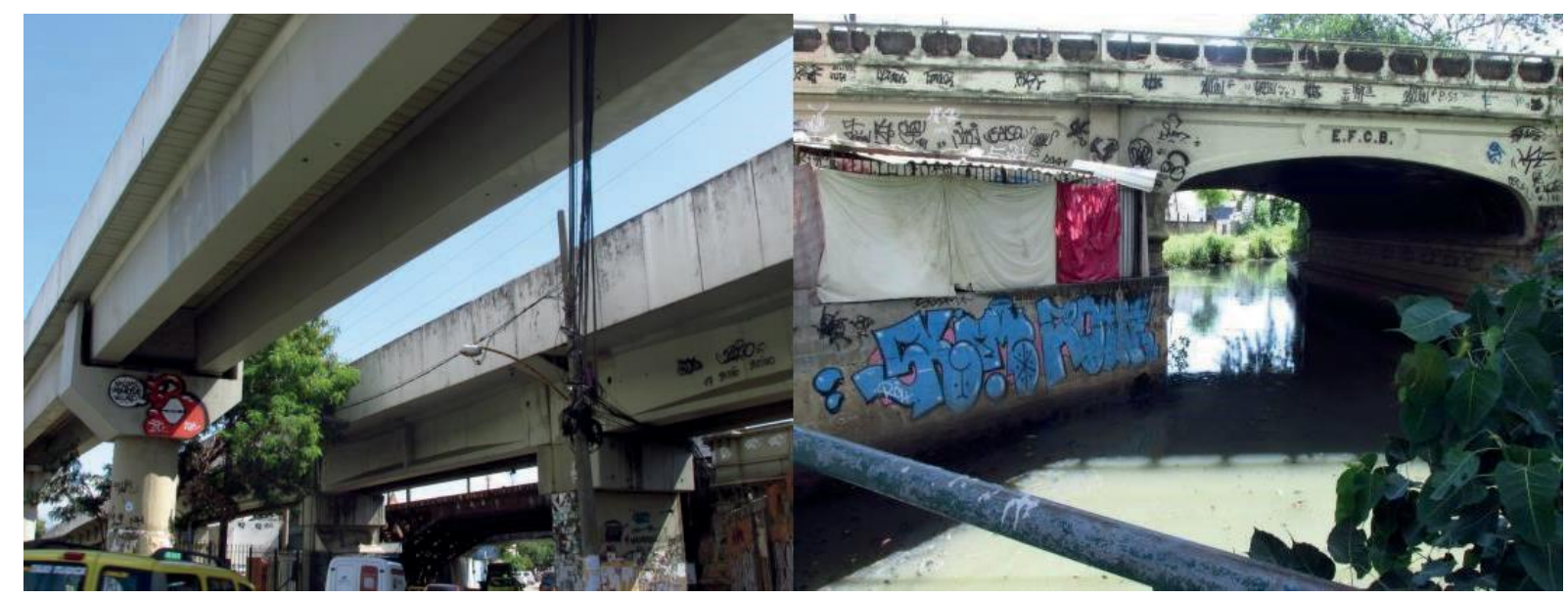

6 Um trem passa ai sobre minha cabȩ̣a e pode ser escutado em 7’24", marca 1 no link já mencionado, em uma passagem saturada. 

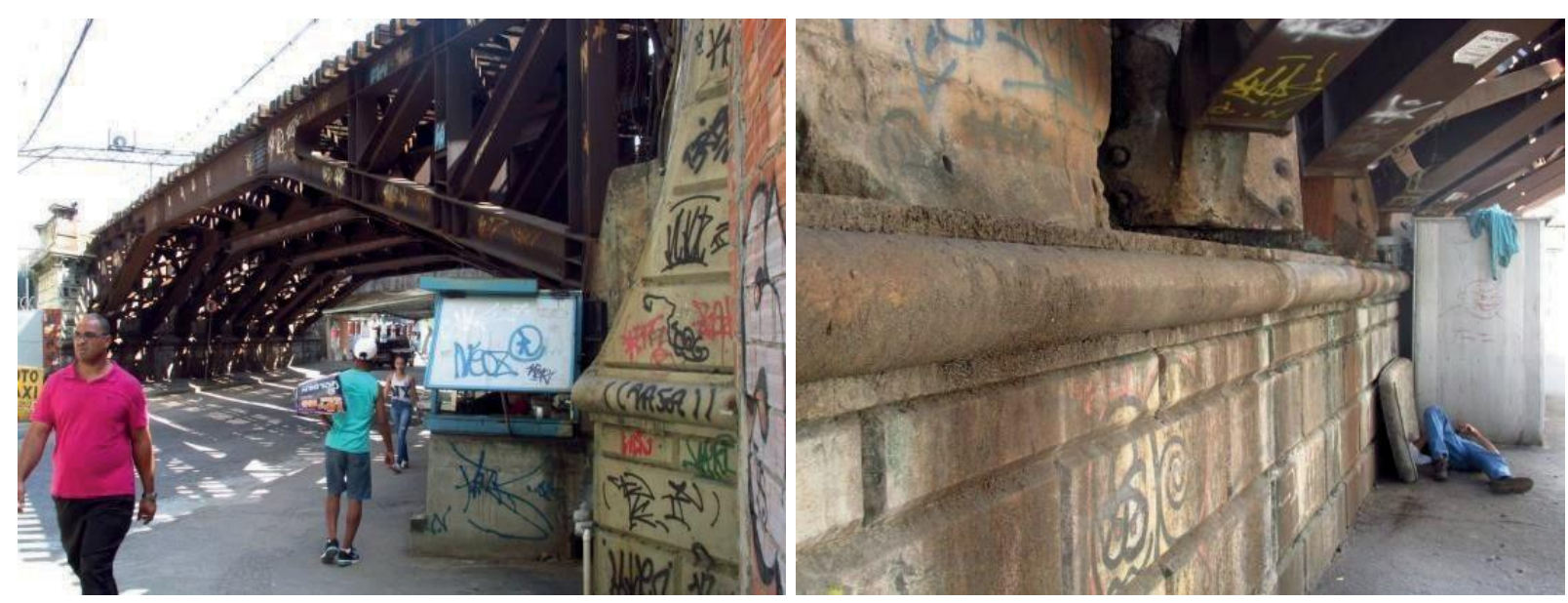

Fig. 4 a 7: Cruzamento entre a Radial Oeste e a rua Ceará. Fonte: Fotografias do autor (2018).

Andando por ali, novos sons e personagens apareceram. Tão logo me esqueci do trânsito pesado da Radial Oeste, escutei um pregão gravado do vendedor de ovos, persistente, anunciado por um megafone em uma Kombi. "Quarenta ovos, dez reais! $\mathrm{O}$ patrão ficou maluco!", dizia a gravação7. Mais tarde, em 10'18” (marca 4 do link acima), um motor de motocicleta com muito volume é escutado. Aquela área é povoada por oficinas em meio a casas muito pobres; por ali lembro-me de uma velha senhora com seu neto passando por mim. Ela conduzia silenciosamente o garoto para a escola. Sua face era sem expressão, autômata.

À medida que me aproximava do centro da zona de prostituição, fui chamado por um velho senhor negro muito elegante. “Como é que é, fotógrafo?”, disse-me. Conversamos um pouco. Ele tirou minha atenção de uma briga entre dois moradores de rua, levando-me também a evitar a rua de prostituição.

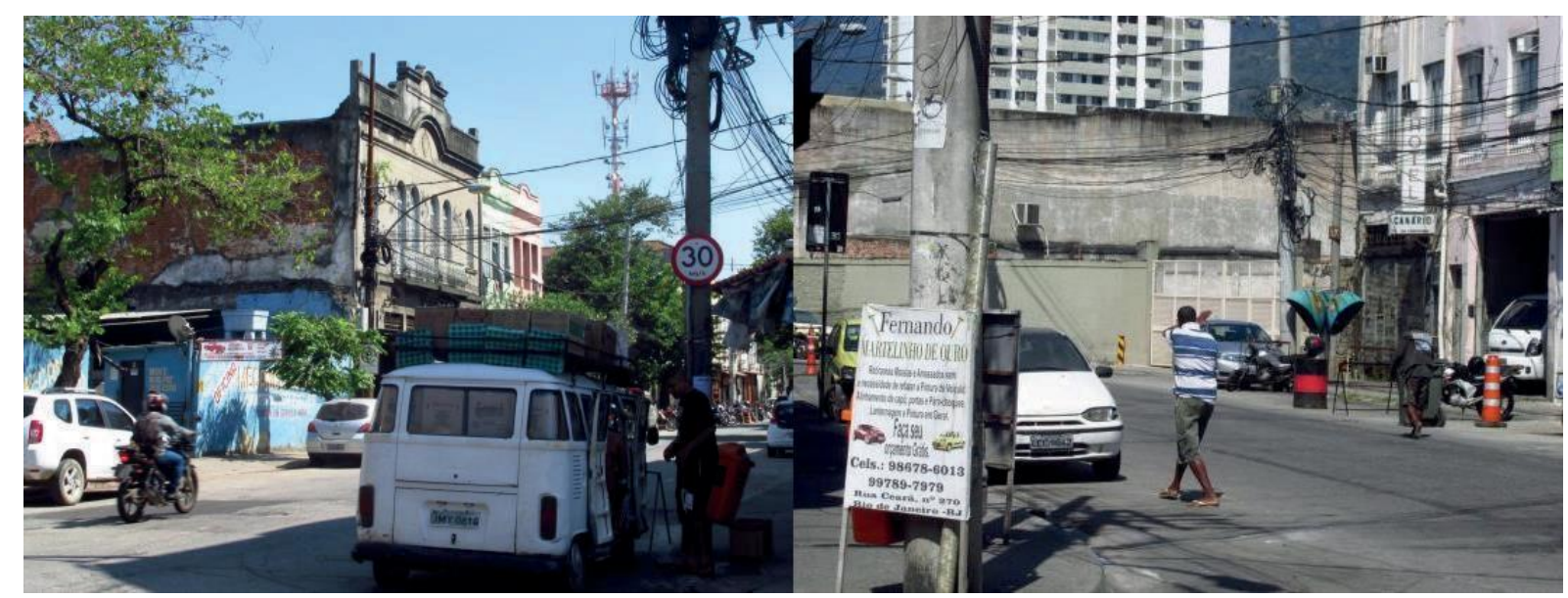

Fig. 8 e 9: Vendedor de ovos.

Imagem 9: Briga de moradores de rua entre as oficinas de motocicletas e hotéis. Fonte: Fotografias do autor (2018).

70 pregio pode ser escutado em 9'14" no link acima. 
Embora soubesse que se encontrava por ali, não me deparei com a zona de meretrício das

proximidades da rua Ceará, a Vila Mimosa. Mas, tão logo a abandonei, encontrei duas prostitutas, agora em uma avenida com tráfego (a Pedro II). Elas estavam trabaIhando, e minha presença foi notada. Silenciosamente, fui intimidado pelos seus olhares. Temendo qualquer animosidade, tomei distância. A hostilidade derivava de uma desconfiança, pois ali eu era um caminhante inesperado. Eu, um homem branco, era um cliente em potencial e deveria, talvez, estar de carro.

\subsection{A região do mangue}

Nas primeiras três décadas do século passado, a região do mangue foi uma zona de prostituição, mas também uma área cosmopolita de coabitação. Antigos escravos, imigrantes italianos e poloneses - todos muito pobres - escolheram viver nestes arredores do porto, encontrando trabalho e moradias baratas.

Parte da área do mangue foi conhecida como Pequena África; no início do século $X X$, a Praça Onze, próxima à Praça da Bandeira, foi o ponto inicial das recém-inauguradas escolas de samba, durante o carnaval. Na Fig. 10 vê-se um grande número de personagens em suas fantasias de carnaval em 1937: travestis, um mosqueteiro, uma garota portando um estandarte da República, outra com uma faixa dizendo "Jornal do Brasil", dois oficiais, um cacique, um homem galante... Não vestem fantasias suntuosas e nem parecem ricos. Com exceção da rainha, ao centro, são um tanto circunspectos para uma festa de carnaval.

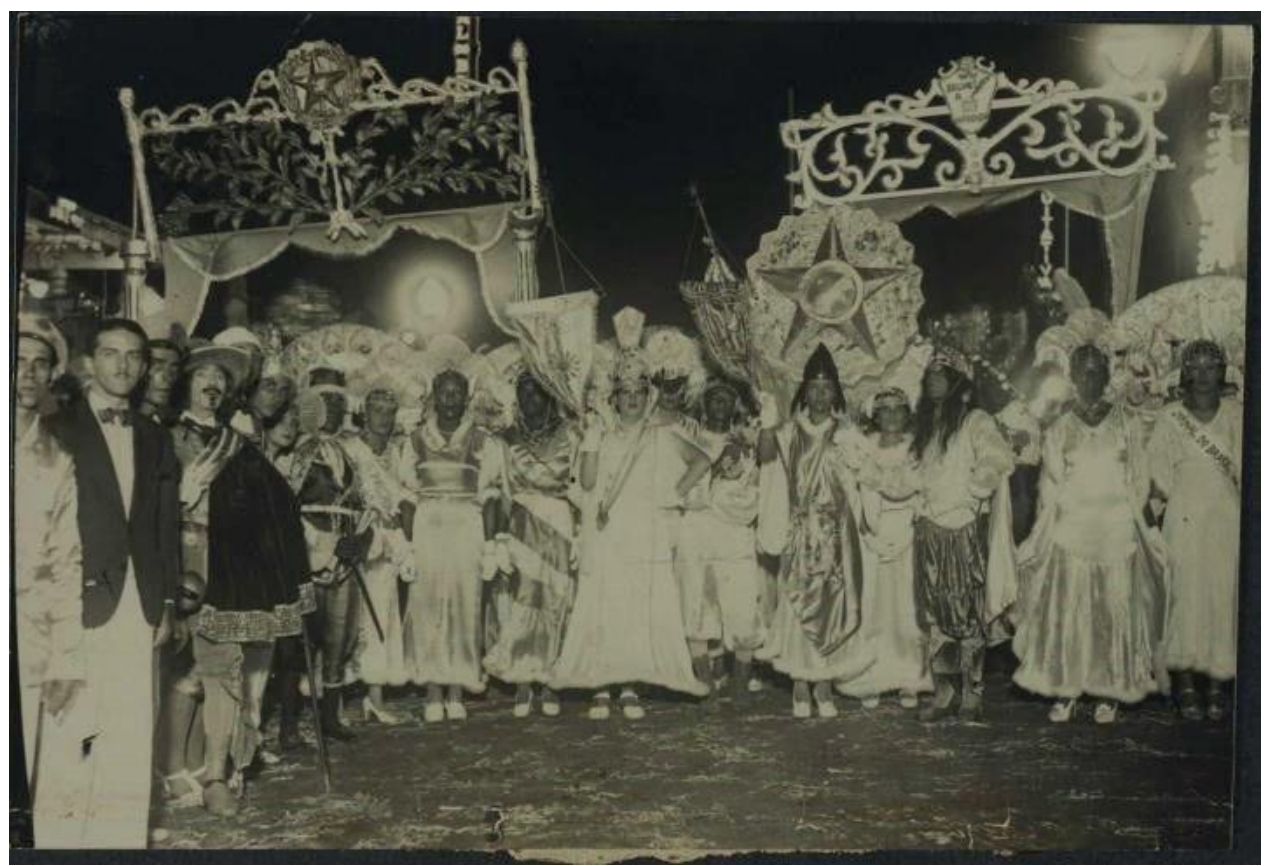

Fig. 10: Carnaval na Praça XI (1937). Fonte: FBN (on-line). 
No prefácio ao livro de gravuras do artista modernista Lasar Segall, Mangue, de 1947 - uma sequência de imagens produzidas a partir da zona de prostituição dos arredores da Praça Onze -, a última queda de uma região já decadente foi assim descrita pelo poeta Manuel Bandeira:

E então vieram as restrições policiais. Os choros desapareceram. A tristeza foi infiltrada pelos bandolins dos cegos. E finalmente o tiro de misericórdia: o fechamento dos bordéis, a dispersão das mulheres, com alguns suicídios patéticos por veneno ou fogo... (BANDEIRA, 1993 [1947], p.478).

A Praça Onze, junto com 525 edifícios, foi destruída para que fosse erguida a avenida Presidente Vargas (ABREU, 1987, p.113), uma típica via para automóveis cuja construção se iniciou nos anos 1940. Mas, persistindo, a frágil população daquela área ainda permanece, escapando de ser dizimada ou removida. Voltando à memória das minhas caminhadas, percebi nitidamente que muito da melancolia que ali senti talvez estivesse ligada ao desaparecimento da vivacidade dos tempos antigos da época do nascimento do samba. Embora ainda não consiga nomeá-la, aparece em mim uma memória que, estranhamente, me pertence e que vem de um passado profundo. Como no poema "Parada de Lucas", de Bandeira, as águas subterrâneas do mangue podem ser o escape da superfície dura das ruas, um reservatório de liberdade ou alegria contra a brutalidade contemporânea:

Ah, se o trem parasse
Minha alma incendida
Pediria à noite
Dois seios intactos.
Parada do Lucas
O trem não parou.
Ah, se o trem parasse
Eu iria aos mangues
Dormir na escureza
Das águas defuntas.
(Canção da Parada de Lucas. BANDEIRA, 1993 [1944]).

O tédio da senhora que levava o neto pelo braço é similar aos rostos que observamos nas gravuras de Segall, ilustrativas das prostitutas e seus clientes nos bordéis. O tédio também é visível na fotografia do carnaval de 1937. É a mesma expressão dos rostos das prostitutas na avenida Pedro II. Este peso, porém, se equilibra hoje contra um ethos que ainda não localizei, mas que sei que é presente. É de uma certa alegria. E então, ambos os aspectos, tédio e alegria, convivem de uma forma que não consigo definir. Mas, para entender esta contradição, talvez eu esteja buscando nos lugares errados. Talvez a escuta das minhas gravações ilumine este aspecto que gostaria de alcançar em uma palavra perdida no contínuo dos sons ou em uma vaga memória. Voltemos às gravações. 


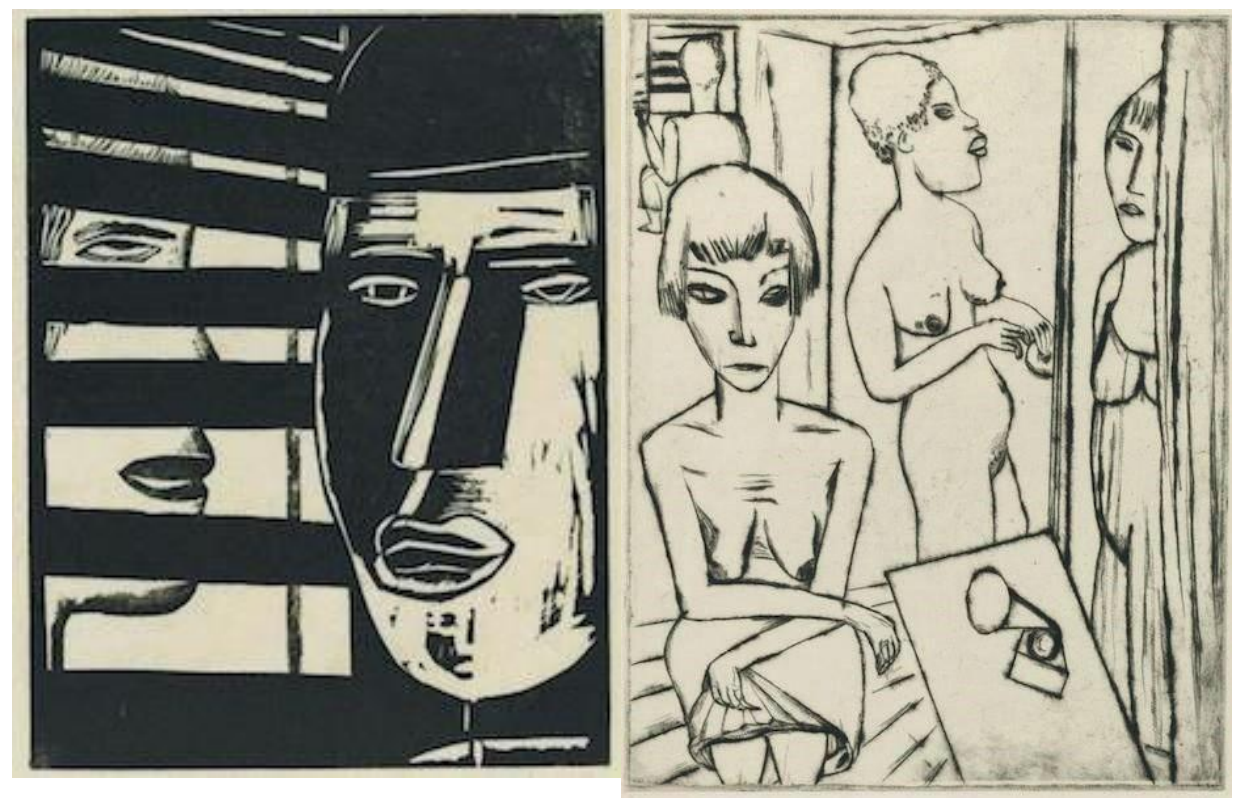

Fig. 11 e 12: Mulheres do mangue com fonógrafo; Casal do mangue com persiana l. Xilogravuras (SEGALL, 1929). Fonte: MLS (Museu Lasar Segall, on-line).

\subsection{Sonoridades do Aterro do Mangue}

O som dos arredores da área do mangue é enquadrado por um fluxo contínuo de automóveis, pois a região é cruzada por enormes avenidas. Os rios de carros estão em todo lugar em minhas gravações e são por vezes tão densos que dificilmente se distingue um automóvel de outro. Mas também o som dos trens sacolejando nos trilhos de ferro está presente. No Rio de Janeiro, esse é o meio de transporte público mais precário, usado pelos segmentos mais pobres da sociedade - o qual compõe também a maioria dos passantes da rua Ceará e arredores: vendedores ambulantes, anotadores do jogo do bicho, garis, prostitutas, vendedores de pão, de coco, de ovos... Como em tempos mais antigos, todo tipo de trabalhadores das ruas: "homens lentos", como se refere a eles o geógrafo Milton Santos. Homens e mulheres que, no capitalismo contemporâneo, não correm pela cidade com a velocidade com a qual o capital é trocado; pessoas cujo caminhar é parte da experiência cotidiana. Ao escutar a gravação, pode-se notar os jargões dos vendedores, os passos, golpes ou outros sons gerados pelas ferramentas de outros trabalhadores. Como um lugar esquecido por sucessivas camadas de urbanização, seriam estas vozes ecos do passado? Os pregões dos vendedores se assemelhariam aos que imaginamos nas gravuras de Debret, que representam a sociedade escravista do Rio de Janeiro do século XIX? 

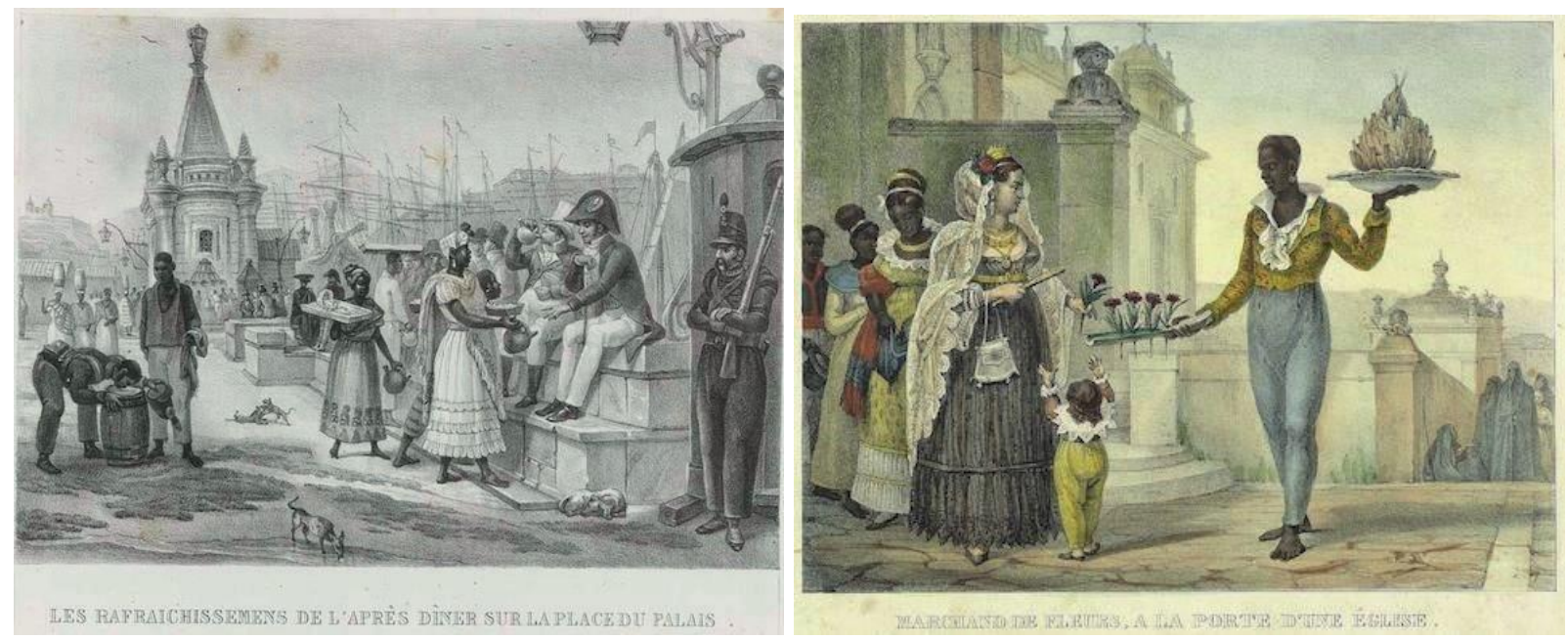

Fig. 13: Les rafraichissemens de l'après dîner sur la Place du Palais. Fig. 14: Marchand de fleurs a la porte d'une église. Litografias (DEBRET, 1835). Fonte: FBN (on-line).

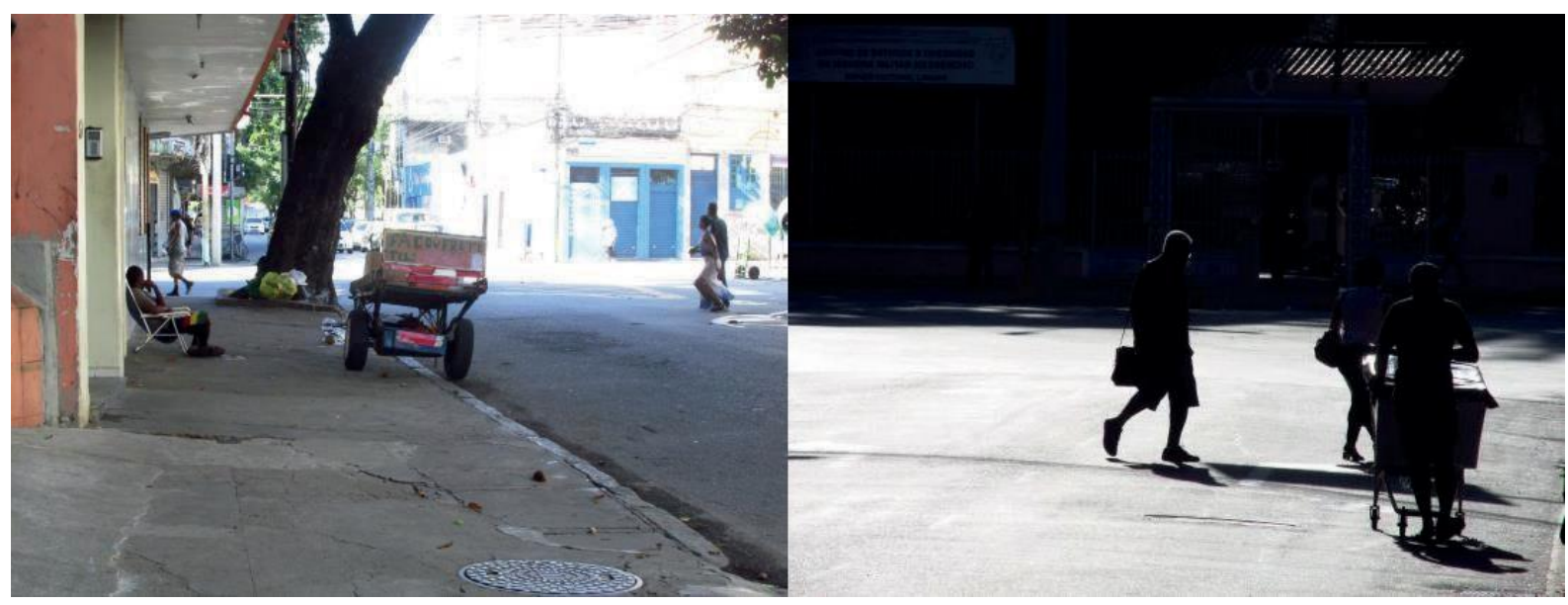

Imagem 15: Carregador. Imagem 16: vendedor de bebidas. Fotografias do autor (2018).

No entanto, em meio a muitos signos de trabalho ou movimento, um evento chamou minha atenção entre tantos outros no fluxo contínuo das gravações. É muito curto: após um longo som de serra, na pausa de seu trabalho, um operário assobiou uma brevíssima melodia de alguns segundos.

Não me lembro de seu rosto, mas seu desenho é para mim uma longa respiração ${ }^{8}$.

\subsection{Recanto}

Mas há um outro lugar de descanso. Tomemos a gravação de 27 de abril de 2018 e

8 O evento ocorre de 27' a 28'05" - marca 5 do áudio já mencionado 
verifiquemos como um todo se evidencia numa forma. Seu trecho central é muito mais silencioso: nenhum automóvel é escutado, além de ser possível perceber os pássaros, e até mesmo os meus passos ${ }^{9}$. Nesse ponto entrei na Quinta da Boa Vista, a única área verde em a toda região do mangue. Era uma sexta-feira de manhã e o parque estava quieto, quase sem ninguém, a não ser um ou outro morador de rua que usava os bancos para dormir, e gatos, naturalmente. Tive uma sensação de alívio ao entrar nessa bolha de silêncio.

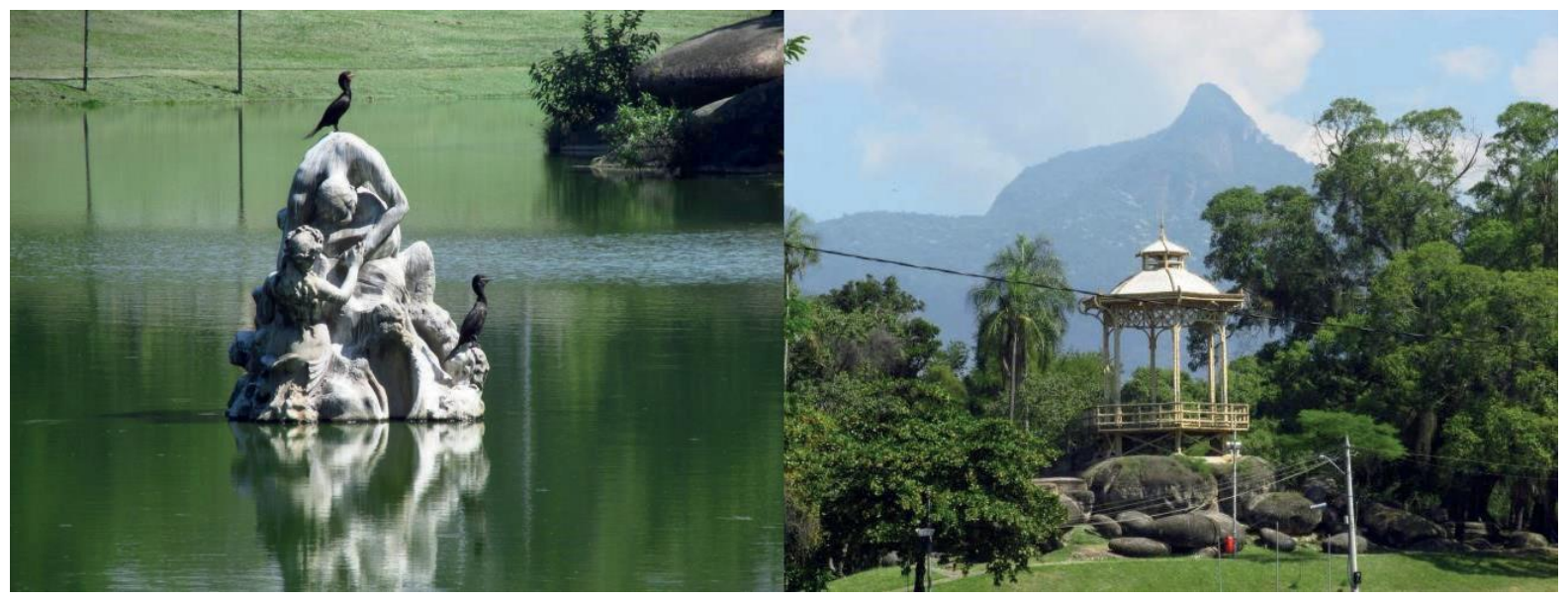

Fig. 17 e 18: Quinta da Boa Vista. Fonte: Fotografias do autor (2018).

\section{5 de setembro de 2018: Quinta da Boa Vista}

Sempre com microfones binaurais, retornei alguns meses depois à Quinta da Boa Vista. A visita deu-se três dias após o incêndio que destruiu completamente o Museu Nacional e dois dias antes do feriado da Independência. Estávamos a dois meses das eleições presidenciais, e o futuro candidato vitorioso seria esfaqueado em um atentado no dia seguinte. $\mathrm{O}$ acontecido o ajudaria a vencer o pleito. Os ânimos do país estavam acirrados.

O clima era cinzento, com nuvens pesadas naquela manhã de quarta-feira de primavera. Cheguei às dez da manhã e havia algumas pessoas correndo ou caminhando com cachorros. Do passado, a calma acenava ao futuro terríveis eventos.

Dentro do parque notei uma forte presença militar, talvez pelo museu incendiado ter sido declarado tardiamente interesse nacional. Eu sabia que naquela hora se iniciava uma assembleia universitária para entender os próximos passos a tomar frente à catástrofe. Esta aconteceria em frente às ruínas.

Evitei caminhar naquela direção intentando escapar do burburinho da política, mas foi inevitável. Três mulheres na direção oposta chamaram minha atenção. Sobre o co-

9 Ocorreentre 38'e46'doarquivo deáudiosupracitado. 
reto oitocentista, elas rezavam e caminhavam em círculos, como as Três Graças Gregas. Elas chamavam para que o Espírito Santo de Deus limpasse aquele lugar, aquele estado e aquele país. "Tudo o que chamam destruição eu chamo construção, meu Deus!", dizia uma delas. "Senhor, salve essa nação, Pai!"

Ao fundo, o som de máquinas podia ser escutado - uma serra elétrica.

Já que era véspera do feriado da Independência, a cavalaria do exército, que tem um quartel nas proximidades, passava pelo parque, ensaiando a parada militar do dia seguinte. Na gravação ela é sucedida da minha aproximação até as Graças ${ }^{10}$.

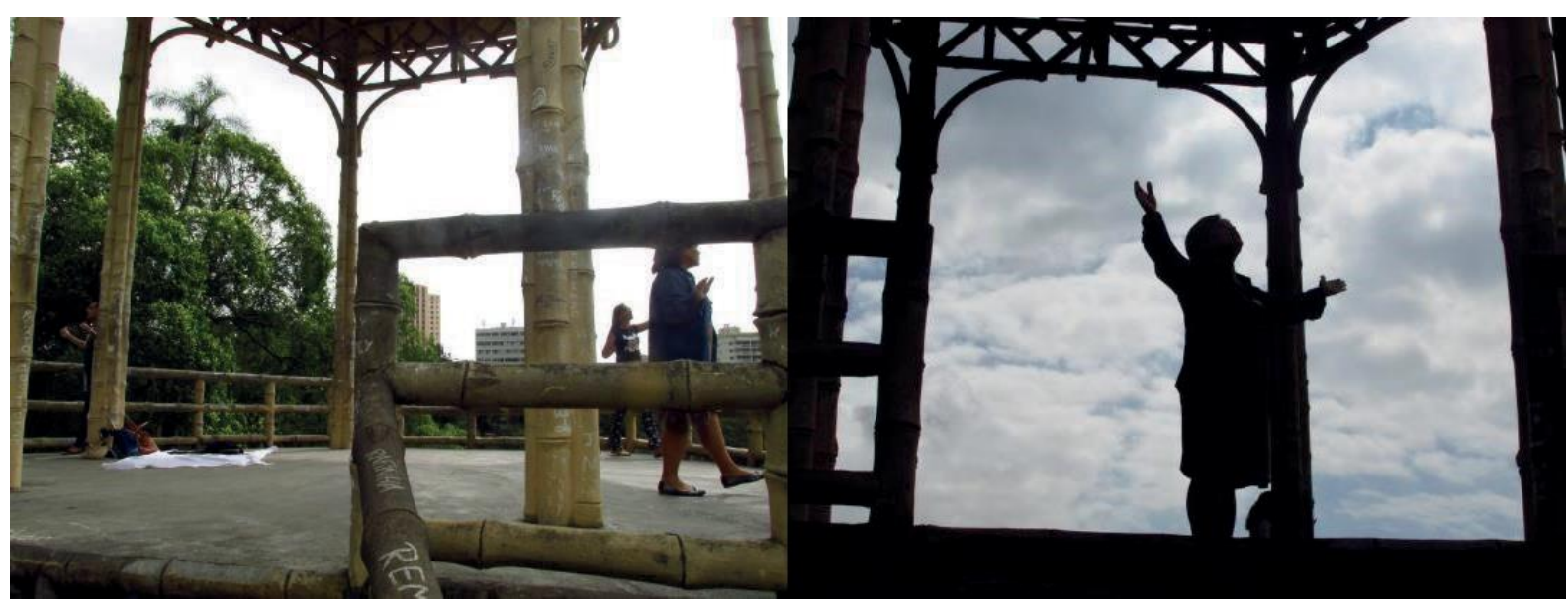

Imagens 29 e 20: As três Graças Cristãs.

Finalmente, me dirigi até a assembleia universitária e o prédio em ruínas, mas este trecho da gravação para mim é o menos interessante. Há o registro das falas dos dirigentes universitários e das conversas do público, mas sua prosódia, o conteúdo do que diziam e os timbres de suas vozes eram estereotipados e desinteressantes. $O$ interesse estava no silêncio entre as palavras: nos olhares atentos dos policiais, soldados do exército e agentes da Polícia Federal que nos cercavam.

Até o dia de hoje nenhuma instituição ou pessoa foi responsabilizada pela destruição do antigo Palácio Imperial. Mas a presença da cavalaria, as vozes das peregrinas, a serra elétrica e o clima com densas nuvens eram talvez o prenúncio de um futuro pesado, que ali se anunciava.

\section{Janeiro a março de 2019: a Baía de Jebebiracica}

A última das minhas investigações de escuta e captura sonora na região do Mangue se deu sob um outro viés: de janeiro a março de 2019 interessei-me pelos rios que, aqui ou ali, se pode vislumbrar e que formam a baía de Jebebiracica. As gravações so-

10 Este caminhar pode ser escutado aqui em https://soundcloud.com/user-472241268/tres-gracas-cavalos. 
noras e as fotografias formaram o material para a instalação "Jebebiracica", apresentada na exposição Rios do Rio, em 2019, no Museu Histórico Nacional do Rio de Janeiro. A instalação consistia em uma difusão sonora em quatro canais e uma série de projeções de fotografias em slide, que, mais tarde, foi substituída por uma exibição dos negativos em uma mesa de luz. Além disso, havia um miniprojetor com uma fotografia estereoscópica do Canal do Mangue - hoje avenida Presidente Vargas -, realizada no século XIX pelo fotógrafo Revert Henrique Klumb, e por fim uma narrativa em áudio sobre o processo de criação, tocada por um fone de ouvido ${ }^{11}$.

As incursões buscavam documentar os rios da baía e seus arredores. Fiz duas visitas em lugares distintos: no piscinão da Praça Varnhagen, na Zona Norte do Rio de Janeiro, e um retorno às redondezas da rua Ceará. Passemos às descrições.

\subsection{O piscinão da Praça Varnhagem}

Em 6 de janeiro de 2019, visitei, com dois ajudantes, este enorme espaço na Tijuca, que consiste em dois poços de quinze metros de profundidade e diâmetro para a contenção das cheias do rio Maracanã, a ele contíguo. Entramos ali por uma portinhola, ao rés do chão, como uma escotilha, e descemos por uma escada de metal cujo som, aos passos, reverberava no volume imenso do espaço. Naquele dia, um fio d'água cobria o fundo do poço salpicado de bolhas, dando aos olhos a textura de uma língua de peixe: um daqueles gigantes amazônicos cujo nome não me recordo, talvez um pirarucu.

A luz do sol entrava por uma grande abertura na linha da rua, uma grade serrilhada que permitia também a entrada da água das enxurradas que se formavam em dias de tempestade, quando a avenida Maracanã se transformava nas margens do rio que nomeia também o bairro e o estádio. Um leve cheiro fétido de folhas podres se impregnava nas narinas e caía um gotejar constante de águas claras que, explicou-nos um engenheiro que trabalhava ali, vinha da drenagem do lençol freático. Esta água, limpíssima, misturava-se ao esgoto do fundo, que recebia tudo.

As paredes de concreto eram tingidas de ocre-ferrugem destas águas e pareceu-me que um dia os vergalhões de ferro que sustentam o cimento irão se esfacelar e desaparecer, sendo que a decadência daquele monumento negativo já teria sido planejada desde sua fundação.

Caminhamos por passarelas de metal, com seus guarda-corpos amarelos, até que avistei uma galeria lateral cujo teto ia se afunilando até reduzir-se à altura de uma criança. Ali, tivemos que andar abaixados. Ao longe vimos um rastro de luz horizontal. Dirigimo-nos até ele, subindo algumas plataformas em escadinhas de escotilha. Foi quando descobrimos, um pouco abaixo do último nível que tínhamos alcançado, o canal de concreto que, como uma armadura de pedra, restringia o curso do rio Maracanã. Acima dele enxergávamos os carros parados no trânsito matinal. Entre nós e o rio havia uma

11 A reduçio em estéreo do áudio projetado na instalação pode ser escutada em: https:/soundcloud.com/user-472241268/jebebiracica. 
grade que, como fomos informados, fora instalada para impedir que o poço se prestasse à moradia de miseráveis que ali se abrigaram na sua inauguração. Foram surpreendidos, nos contou o engenheiro, na primeira cheia do rio: um homem teria morrido afogado.

O som do trânsito e de nossos passos era tingido por uma longuíssima reverberação grave que trazia matizes ainda mais sombrios à caverna de concreto. Nas águas arrastava-se um constante redemoinho que dava a impressão de que nelas havia algum estranho animal, resquício abissal de vida em condições tão insalubres. O engenheiro, aliás, informou-nos que vivem ali peixes, sapos e pequenos répteis.

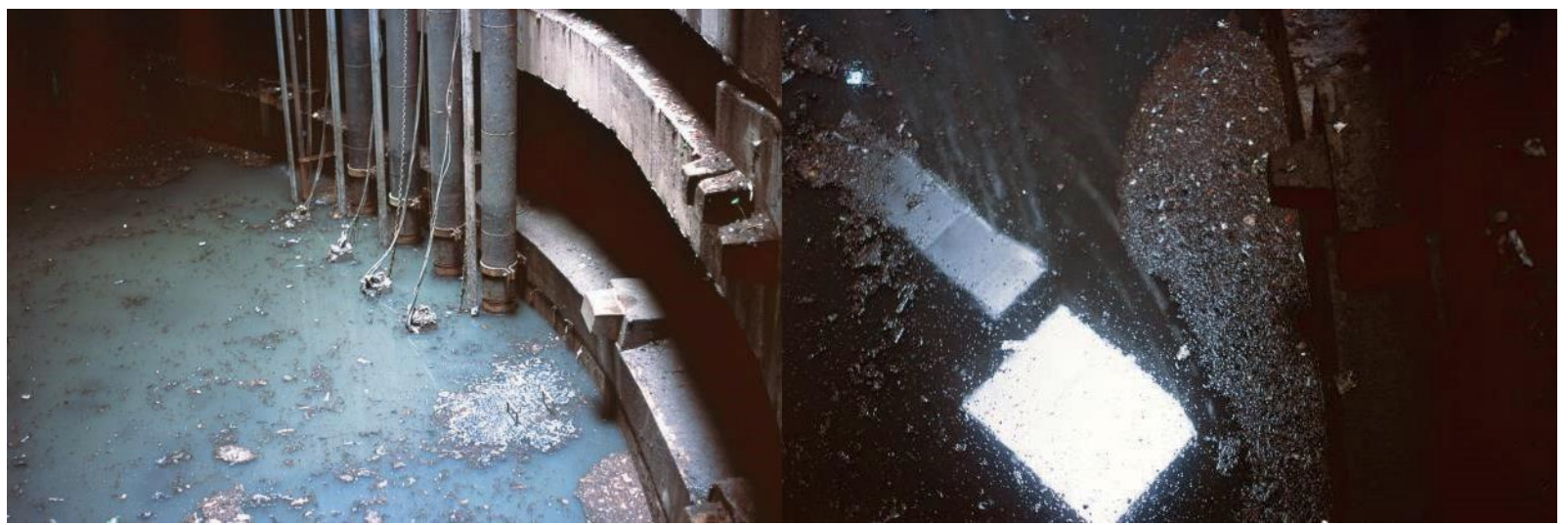

Fig. 21 e 22: 0 interior do piscinão da Praça Varnhagen. Fonte: Fotografia em slides pelo autor (2019).

\subsection{De volta à rua Ceará}

Em uma outra incursão, um ajudante e eu caminhamos em um percurso que foi do início da rua Ceará, passando pela Vila Mimosa e pela avenida Francisco Eugênio, para, por fim, chegarmos à avenida Francisco Bicalho até a rodoviária. Nosso objetivo era o de seguir a pé e pela superfície o suposto trajeto do rio Joana, visível apenas na esquina da rua Ceará com a Radial Oeste, até o Maracanã (na Francisco Eugênio), que desemboca no Canal do Mangue e este no mar, ali perto da rodoviária.

No valão que se vê na rua Ceará há um entroncamento de pontes ferroviárias de aço fundido em que se lê EFCB e uma data, 1905. Paramos um pouco por ali e observamos o lamaçal que corre lentamente, cujo cheiro de cerveja rescinde embaixo das pontes. Em intervalos irregulares passam os trens e o metrô, causando um estrondo imenso e curto, aparição desproporcional à calmaria assustadora e decadente de sucatas de televisores empilhados e um ou outro passante: um trabalhador e muitos moradores de rua, todos silenciosos.

A ponte sobre o canal forma um arco, suas águas refletindo as ogivas art noveau, testemunho de tempos melhores. Vimos garças futucando as águas podres e ficamos imaginando que tipo de vida haveria ali. Depois de mergulharmos o microfone subaquático e captarmos o som dessas águas, fomos embora meio desolados.

Passamos os viadutos e dobramos a primeira rua à esquerda, colada ao rio, que 
dali não pode mais ser visto: um muro alto o encobre no lado direito. No esquerdo alternam-se cortiços e lugares de recolhimento de ferro-velho e lixo. Vimos crianças, velhos e homens de bermuda sentados nas soleiras das portas. A antiga região do Mangue alaga até hoje, e, portanto, há um forte cheiro de esgoto e umidade ao longo desta pequena rua esquecida por todos.

Ela acaba uma quadra à frente. Dobramos à esquerda e entramos sem querer na rua da Vila Mimosa - zona de prostituição ainda em atividade. Os prostíbulos, pelo que sei, foram transferidos da Cidade Nova para lá nos anos 1980 para a construção da Prefeitura e de outros prédios administrativos - daí o apelido Piranhão da atual sede do governo municipal carioca. Com os anos, a Vila Mimosa vem vivendo um lento desaparecimento. Mas passamos por ali à tarde de um dia de semana e mesmo assim encontramos clientes e moças vestidas para os programas: algumas de biquíni e microshort, o traje mais comum.

Os prédios são um misto de boteco e moradia. Televisores para fora, uma ou outra jukebox e churrasquinhos na rua - tudo dá a aparência de um movimento que nunca dorme.

A Vila Mimosa termina na rua Ceará. Fomos indo nela até nos depararmos com um enorme terreno baldio. Entramos. Nele era possível ver, onipresente, o Pico da Tijuca, um matagal imponente, e, do lado esquerdo, um casarão que parecia habitado, embora quase em ruínas. Na caminhada anterior, o senhor elegante que passava por ali me informou ser a antiga sede do ramal ferroviário Francisco de Sá, desativado há mais de 40 anos. A ruína, o espaço para os vagões, tudo isso ainda estava presente, nem restaurado nem demolido: um vazio bem no meio da cidade - área urbana em que a natureza ainda tem a possibilidade de evoluir. Estávamos a poucos metros da rodoviária, uma área de grande concentração de automóveis, mas nesse lugar pairava um silêncio total em que não se escutavam nem vozes nem máquinas: apenas o farfalhar do vento na vegetação. Saímos dali e seguimos até a Francisco Eugênio, avenida pela qual vagueia lentamente o rio Maracanã. No meio do canal vejo um galho enfincado ao chão. Outra garça bica não sei o que entre o cano de esgoto e o fio d'água. O quartel da PM, de arquitetura neogótica, é refletido pelo rio. Traz os ares de histórias de cavalaria em meio aos carros Uno e Corsinha dos policiais. Ninguém passa por ali; nenhum transeunte se aventura por essa via que acaba em viadutos e canais e começa na zona de prostituição; apenas um ou outro automóvel a percorre. 


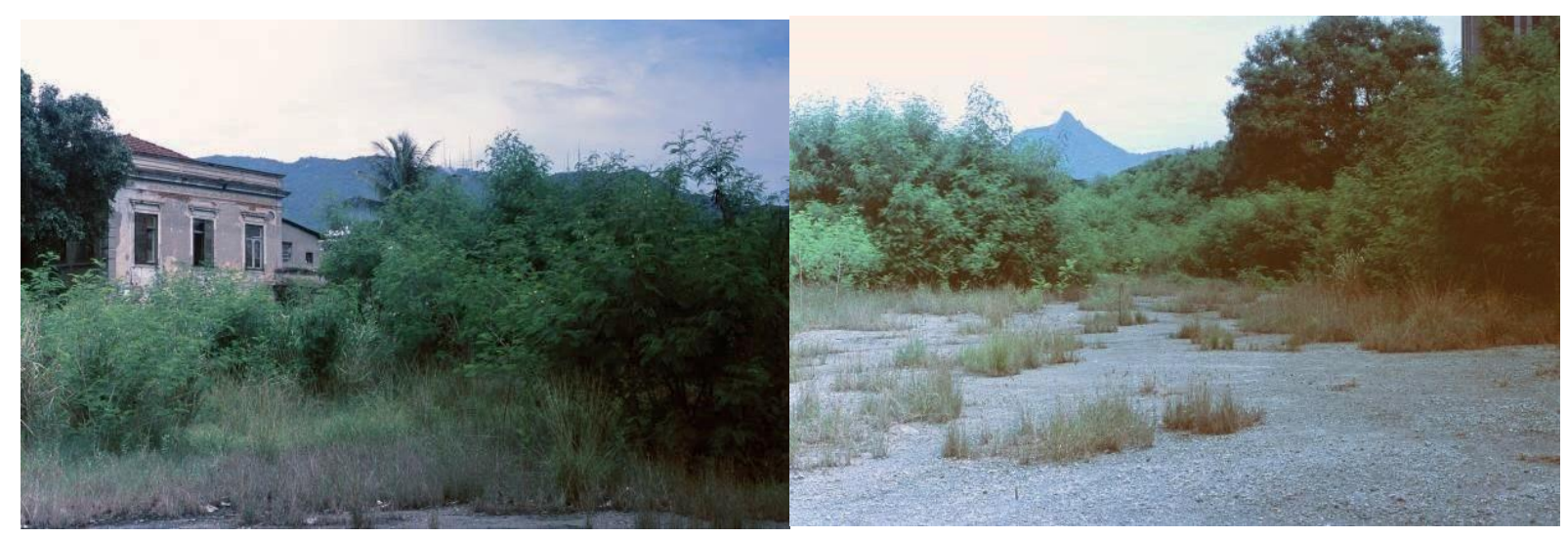

Fig. 23 e 24: Casa em ruínas e a paisagem do Pico da Tijuca. Fonte: Fotografias em slides pelo autor (2019).

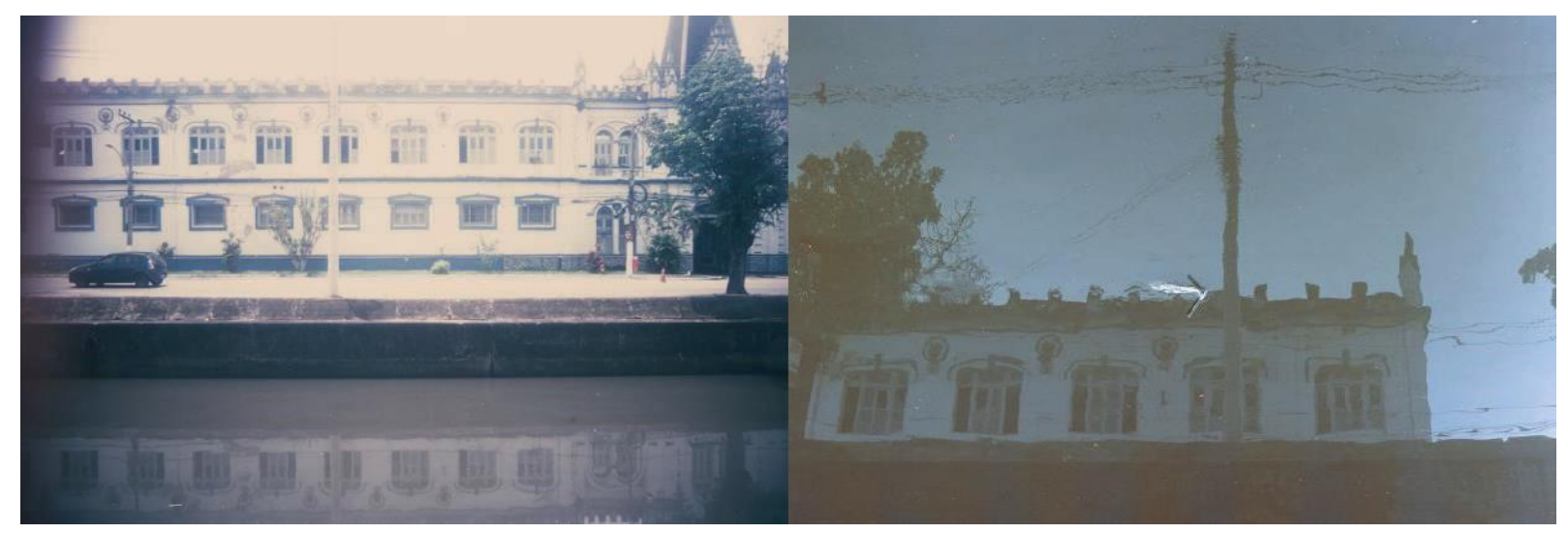

Fig. 25 e 26: 0 antigo quartel da Polícia Militar. Fonte: Fotografias em slides pelo autor (2019).

\section{Conclusões}

A caminhada e a gravação realizadas em 27 de abril de 2018 revelam para mim sentimentos opostos com relação à região em que vivo. Sinto a melancolia entre as pessoas de hoje e de outros tempos. Sua fonte talvez se relacione com o passado do Rio de Janeiro: o sistema escravista e os processos brutais e periódicos de modernização que ultrapassam e soterram culturas, a natureza, antigas arquiteturas e modos de vida. A paisagem de hoje é uma área abandonada da cidade - região esquecida que, entretanto, carrega fortes símbolos para sua identidade.

Por outro lado, a presença de pessoas nas ruas traz as suas vozes e os sons de seu trabalho; de tempos em tempos, uma escuta atenta pode resgatar sopros de vida, espaços de descanso e segmentos sonoros de outras épocas. O chacoalhar do antigo sistema ferroviário, o pregão dos vendedores e mesmo o tom de voz das pessoas são signos relacionados a uma persistência do passado. Pela sua própria existência, eles são o sinônimo de uma vitória e de um escárnio contra a modernidade.

O antigo palácio imperial e seus arredores, visitado antes e depois de sua destrui- 
ção, é ao mesmo tempo ponto de descanso e confluência de alguns símbolos ligados à nacionalidade, religião e cultura, mas os modos de atualização destes ícones são os de uma decadência física e cívica. Cada um destes modos em decadência é clara e simultaneamente audível na minha segunda visita, como camadas de uma polifonia. A coexistência das Três Graças Cristãs com a cavalaria e os estereotipados discursos dos acadêmicos (oprimidos pela forte presença militar) são, arrisco dizer, signos premonitórios das mudanças na democracia brasileira, tal como percebo agora, passado mais de um ano da sua gravação - mas acredito que a intensidade de tal confluência de signos é algo ainda a ser entendido no futuro.

Finalmente, as visitas na baía de Jebebiracica mostraram-me o absurdo do sistema de águas atual, que transformou todos os rios em esgoto fechado ou aberto. O método de contenção das águas durante a sua expansão devido às chuvas consiste em enormes e imponentes construções negativas, recônditas e subterrâneas, que apresentam uma realidade paralela com relação à superfície. Sua sonoridade é inaudita em qualquer espaço da cidade, tanto pelas águas perenes quanto pela alta reverberação de fontes sonoras que estão no nível do chão. É também um cenário quase irreal, com animais subaquáticos imaginários só visíveis e audíveis por eventos discretos e misteriosos.

A caminhada pelas ruas da região da rua Ceará é, em muitos aspectos, o encontro com espaços negativos ou opacos, como Careri ou Santos poderiam tê-los denominado. A enorme casa e o terreno baldio da estação de trem abandonada, e mesmo a configuração geral das ruas, com seus poucos passantes, tudo isso são elementos de um espaço opaco da cidade. Apesar de ser localizada em uma área central, a região é esquecida pelo capital e pela modernidade. Entretanto, estes espaços possuem a beleza de uma ruína, eco de antigos tempos de prosperidade que podem ser percebidos através de traços de refinamento arquitetural. Os prédios antigos sem uso e sem uma relevância patrimonial evidente não foram demolidos, e uma nova cidade ali não tem horizonte futuro. Os homens e as mulheres lentas, que passam por esta arquitetura e por esta paisagem extremamente poluída em suas jornadas cotidianas, preservam estes espaços vivos e em uso, mas em outro ritmo e outra temporalidade com relação ao resto da cidade.

A experiência de andar, escutar e gravar a região em que vivo criou em mim uma forte ligação, visto que me lembrar das caminhadas por via das gravações e das fotografias é uma forma de ampliar a memória dos detalhes e camadas não percebidas durante a caminhada em si. É uma forma, portanto, de aprofundar uma experiência já vivida. Assim, o argumento de Feld de que o som é uma forma de conhecimento tornou-se mais evidente para mim após as três visitas: o entendimento da minha região se dá agora em outro nível de acuidade, e só pela reescuta pude analisar o que havia notado nas caminhadas. A estratégia de gravações binaurais revelou uma paisagem sonora não usual, distante de pontos turísticos ou de espaços modernos, tais como as áreas mais ricas ou mais pobres, todas com uma lógica muito racional. É uma outra cidade, opaca no sentido que dá Careri, que se mostrou para mim: muitos dos lugares visitados são ausentes do constante tráfego que homogeneíza as sonoridades urbanas. Ao mesmo tempo, pude escutar a presença de pessoas cujo modo de vida se dá pelo caminhar, 
o qual se mostra pelos seus pregões, assobios, chamados ou interjeições, e que estão ligados tanto ao seu modo de se movimentar quanto à sua atividade: espaço negativo que se mostra para a escuta e se abre para o detalhe e para o particular.

\section{Referências}

BANDEIRA, M. Poesia completa e prosa. Rio de Janeiro: Nova Aguilar, 1993 [1944].

BERENSTEIN, P. Elogio aos errantes. Salvador: Ud. UFBA, 2014.

CARERI, F. Walkscapes: o caminhar como prática estética. São Paulo: Gustavo Gili, 2013.

CARERI, F. Caminhar e parar. São Paulo: Gustavo Gili, 2017.

CAUX, J.; FERRARI, L. Presque Rien avec Luc Ferrari. Paris: Main d'Oeuvre, 2002.

DROTT, E. The Politics of Presque Rien. In: ADLINGTON, R. Sound commitments: avant-garde and the sixties. New York: Oxford University Press, 2009.

FELD, S. Acoustemology. In: NOVAK, D.; SAKAKEENY, M. Keyword in sound. Durham: Duke University Press, 2015.

FENERICH, A. S. A inscrição da intimidade na Symphonie pour un Homme Seul. Tese (Doutorado em Artes) - USP, São Paulo, 2012.

FENERICH, A. S. Wanderings through the aterro do mangue of Rio de Janeiro. In: BREITSAMETER, S.; KARAKIZ, C. The Global Composition2018: conference on sound, ecology and media culture - proceedings. Dieburg: Hochschule Darmstadt, 2018.

FOSTER, H. O retorno do real. São Paulo: Cosac Naify, 2014.

GILKEY, R.; ANDERSON, T. Binaural and spatial hearing in real and virtual environments. New York: Psychology Press, 2014.

GUTIERREZ, A. Flâneuse>La caminanta. In:BREITSAMETER, S.; KARAKIZ, C. The global composition 2018: conference on sound, ecology and media culture - proceedings. Dieburg: Hochschule Darmstadt, 2018.

KIM-COHEN, Seth. In the blink of an ear: toward an non-cochlear sound art. New York: Continuum, 2009. 
LA BURTHE, A. The immersive power of binaural sound: an interwiew with Amaury La Burthe. [Entrevista cedida a] Benjamin Huguet. CMF Trends, 25 jan. 2017. Disponível em: https://trends.cmf-fmc.ca/the-immersive-power-of-binaural-sound-an- interviewwith-amaury-la-burthe-audiogaming/. Acesso em: 23 jun. 2020.

NANCY, J. Listening. New York: Fordham University Press, 2007.

SANTOS, M. Técnica espaço tempo: globalização e meio técnico-científico informacional. São Paulo: Hucitec, 1994.

SANTOS, M. Elogio da lentidão. Folha de S.Paulo, São Paulo, 11 mar. 2001.

SCHAEFFER, P. À la recherche d'une musique concrète. Paris: Éditions du Seuil, 1952.

SCHAUB, M.; CARDIFF, J. Janet Cardiff: the walk book. Viena: Thyssen-Bornemisza Art Contemporary, 2005.

SMALLEY, D. La Spectromorphologie. Une explication des formes du son. Ars Sonora, n. 8, p. 64-114, 1999.

WESTERKAMP. H. Soundwalking as Ecological Practice. Hildegard Westerkamp, 3 nov. 2006. Disponível em: http://www.hildegardwesterkamp.ca/writings/writingsby/?post id $=14 \&$ title=\%E2\%80\%8Bsoundwalkin g-as-ecological-practice. Acesso em: 20 fev. 2019. 